\title{
Food Security Status of Rural Households in Lay Gayint Woreda of South Gondar Zone, Amhara Region, Ethiopia
}

\author{
Girma Zewdie Tizazu \\ Project Manager in Organization for Rehabilitation and Development in Amhara (ORDA) \\ Menberu Teshome Zeleke \\ Department of Geography and Environmental Studies, Debre Tabor University, Ethiopia
}

\begin{abstract}
Ethiopia is among the food insecure countries in sub-Saharan Africa. The problem is more common in Amhara region where nearly $50 \%$ of the Woredas (districts) are found to be sufferers of food shortage. This food crisis is a key development challenge at the present time. Lay Gayint is one of these Woredas of the state suffering from recurrent food deficit. However, there are no detailed studies done using standard methods and measurements to determine food security situations of the people there. Therefore, the purpose of this study was to decide on the food security status of households living in rural parts of the Woreda by using a Core Food Security Module (CFSM). To achieve this objective, data were collected from 379 randomly selected households. A sampling procedure with two stages was used to select sample places and households. In the first stage, five Kebeles were selected proportional to areal coverage of each agro-ecological zones using probability sampling technique. In the next stage, 379 household heads were taken from each Kebele proportional to the size of each Kebele household population using systematic random sampling technique. Data were analyzed using Core Food Security Module (CFSM) and descriptive statistics. The result revealed that about $85 \%$ of the surveyed sampled households were food insecure at different levels. Despite all the efforts exerted by the Ethiopian Government to ensure food security, too low achievement is being recorded. Since food security status is determined by complex factors, comprehensive interventions need to be implemented to enhance food production. Enhancing farmland productivity through integrated watershed management and better technology packages anchored with awareness creation and skill training is imperative. Moreover, strengthening access to and usage of rural credit by linking farmers to extension and family planning measures among others are important strategies to ensure food security.
\end{abstract} Keywords: Core Food Security Module, Food Security, Lay Gayint, Rural Households

DOI: $10.7176 / \mathrm{JAAS} / 57-03$

Publication date: August $31^{\text {st }} 2019$

\section{INTRODUCTION}

It is an absolute fact that food is a fundamental right that influence human ability to live, grow well and acquire information and skill (Morduch, 1995). Optimal physical, reasoning and emotional development in human being requires access to adequate amount and quality of food throughout the lifespan (Cook and Frank, 2008). Given the many undesired consequences associated with poverty and hunger, food insecurity is an important cause of harm to the well-being of human beings.

The concept of food insecurity is defined and explained differently by various scholarly communities and organizations. As to Seligman, Laraia, Kushel (2010), Mazumdar (2012) and Keino, Plasqui, van den Borne (2014) food security is defined as a condition that exists when household members exposed to limited or uncertain physical and economic access to safe, sufficient and nutritious food to meet their dietary needs or food preferences for a productive, healthy and active life. This could be due to lack of access, limited purchasing power, unfair distribution, or inadequate consumption at household level (Carlson et al., 1999). Carlson et al. (1999) also noted food insecurity to be understood in terms of recurrent food crises and famine in the globe.

Globally, food insecurity has been a cause for concern and is still a major problem in affecting people's health, productivity and survival. Efforts to overcome the development challenges caused by food insecurity inevitably start with deciding food uncertainty and identifying the causes at household level (Carlson et al., 1999; FAO et al., 2013).

Food and Agriculture Organization's (FAO's) recently indicated that 842 million people (one in eight people or $12 \%$ of the global population) were suffered from chronic hunger and not able to meet their dietary energy needs in 2011-13. The vast majority of hungry people, 827 million (98.21\%) live in developing regions. Food shortage occurs in many countries to varying degrees, $75 \%$ of the food insecure people live in the rural parts of the developing countries, in which two thirds of these live in Bangladesh, China, Democratic Republic of Congo, Ethiopia, India, Indonesia and Pakistan (Keatinge et al., 2011; Khush et al., 2012). In the same referenced year, 226.4 million people (21.2\%) in Africa: 3.7 million (less than 5\%) in Northern Africa and 222.7 million people $(24.8 \%)$ in Sub-Saharan Africa were estimated to be unable to meet their dietary energy requirements (FAO et al., 2013). 
Most of the estimated deterioration in food security happens in Sub Saharan Africa (SSA), which is the only region estimated to have an increase in the number of food insecure people in the next decade. It is projected to rise from about 254 million in 2013 (30\%) to 373 million (34 \%) food insecure population in 2023 (Meade et al., 2013 The problem of food crisis is aggravated by several inter-related factors, In the light of this, in recent times, media headlines have highlighted the most extreme dangers associated with changing climatic conditions, including recurrent droughts, floods, heat-waves, intensified storms and land degradation. Human-caused climate change puts in new unexpected threats to societies not only due to the occurrence of these extreme events but also due failures to adequately address persistent poverty (Schipper, 2004) and severe land degradations (World Bank, 2008; FAO, 2009). Moreover, over 400 million people are living in at least 17 drought prone Sub-Saharan Africa countries. Lack of sufficient water will badly constrain food commodity production, ecological system protection and socio-economic development. Hahn et al. (2009) notice that the convergence of multiple factors joined with lack of resources for adapting the situation are presenting critical challenges for communities living in Africa who are struggling to cope with and adapt to climate and environmental changes.

Ethiopia lies within one of the most food insecure regions in the globe with a large number of population living at subsistence levels and dependent on farm production which is highly vulnerable to severe droughts. The total volume and per capita food production have shown tremendous fluctuations from year-to-year. Hence, shortage of food has been the most dominant problem in the country. Several reasons have been given by many authors and government officials for this persistent problem of food insecurity. Among these reasons, drought is mentioned frequently. In fact, the root cause of food insecurity and famine cannot be attributed to one particular reason alone; it is the cumulative effect of a multitude of factors. Hence, many authors impute these problems to poor economic policies that have inhibited the development of agriculture, and growing population pressures combined with depleting of the natural resource base, lack of incentives and extension services for the smallscale farmers. In fact, recurrent drought years have significantly affected the country's subsistent agriculture based economy and changed transitory food shortages into chronic food shortages and abject poverty. Moreover, rapid increase of human and livestock population might have caused the carrying capacity of the fragile environment in some areas to be approached or exceeded. As a result, food shortage and famine which previously were only the problems of eastern part of the country are increasingly encroaching the areas which historically have been surplus producing and of high agricultural potential (Gezahegn, 1995; National Food Security Strategy/NFSS, 2002).

Amhara region is one of the largest regions in Ethiopia which comprises 129 rural and 38 urban Woredas. Among the existing rural Woredas of the region, 64 of them are identified as food insecure. Lay Gayint Woreda is one of the food insecure Woredas which is reflected by insufficient food production due to decreasing soil fertility, increasing scarcity of productive farmland, high rate of population growth and limited off-farm/nonfarm economic activities. These conditions are exacerbated by climate variability (Lay Gayint Woreda Office of Agriculture, 2014). Therefore, this Woreda is considered as food insecure merely by its history of emergency food aid reception. However, there are no detailed studies done using standard tools and methods so far. Hence, this assessment was initiated to clearly decide the food insecurity status of households living in rural areas of Lay Gayint Woreda, South Gondar Zone, Ethiopia

\section{Theoretical (Conceptual) Frameworks of Food Security}

Food security is described as sufficient access to food at all times, in all months of the year and from year to year (Hoddinott, 1999). Food security is also defined in the following way. Access by all people at all times to sufficient food for an active and healthy life. Food security includes to the lowest possible degree: (1) availability of sufficient nutritious foods, and (2) an assured capacity to get foods in ways that is acceptable socially (Bickel et al., 2000). When food insecurity becomes more severe it can be expressed by the term hunger which causes hurting sensation resulted from repeated occurrence and inability to have access to food. The terms food insecurity and hunger are used here, as conditions that happen for the reason that households do not have sufficient food or money to purchase food. Hunger, from this perspective, could be seen as a harsh stage of food insecurity. Although this condition is usually connected with poverty, it is not the same as general inadequacy of food or money. Rather, it is the condition of deprivation; it measures the severity of poverty due to resource shortage in this specific area of need, as directly experienced and explained by respondents (Bickel et al., 2000).

Access to food is ensured when all members in the households have adequate resources to get nutritious diet (Hoddinott, 1999). According to Tefera (2009), access can also be achieved without households' being selfsufficient in food produce, what is more important is the capacity of households to generate enough income to meet food need requirements. Households strive to acquire food and exert efforts within the limit of physical, policy and social environment. The physical environment plays a big role in deciding the type of activities that can be implemented by rural households. Government policies toward the agricultural sector will have a powerful impact on the planning and implementation of households' food security interventions.

The resources, or endowments, of households can be seen into two categories: labor and capital. Labor can 
be seen as the availability of labor force for production. It includes both the physical and the human capital dimensions. Households earmark these endowments across different activities such as production of food and off/non-farm activities which generate income to the household in response to the return each activity will bring (Gulled, 2006). Capital refers to those resources such as, financial resources, tools used for on-farm and off/nonfarm production, and land that, when joined with labor produce income (Hoddinott, 1999).

Besides, households could get remittance from relatives, transfer income from the state or nongovernmental organizations (NGOs). Together, all these determine households' income. Households also face a set of prices that determine what level of consumption can be supported by this level of income (Dereje, 2005).

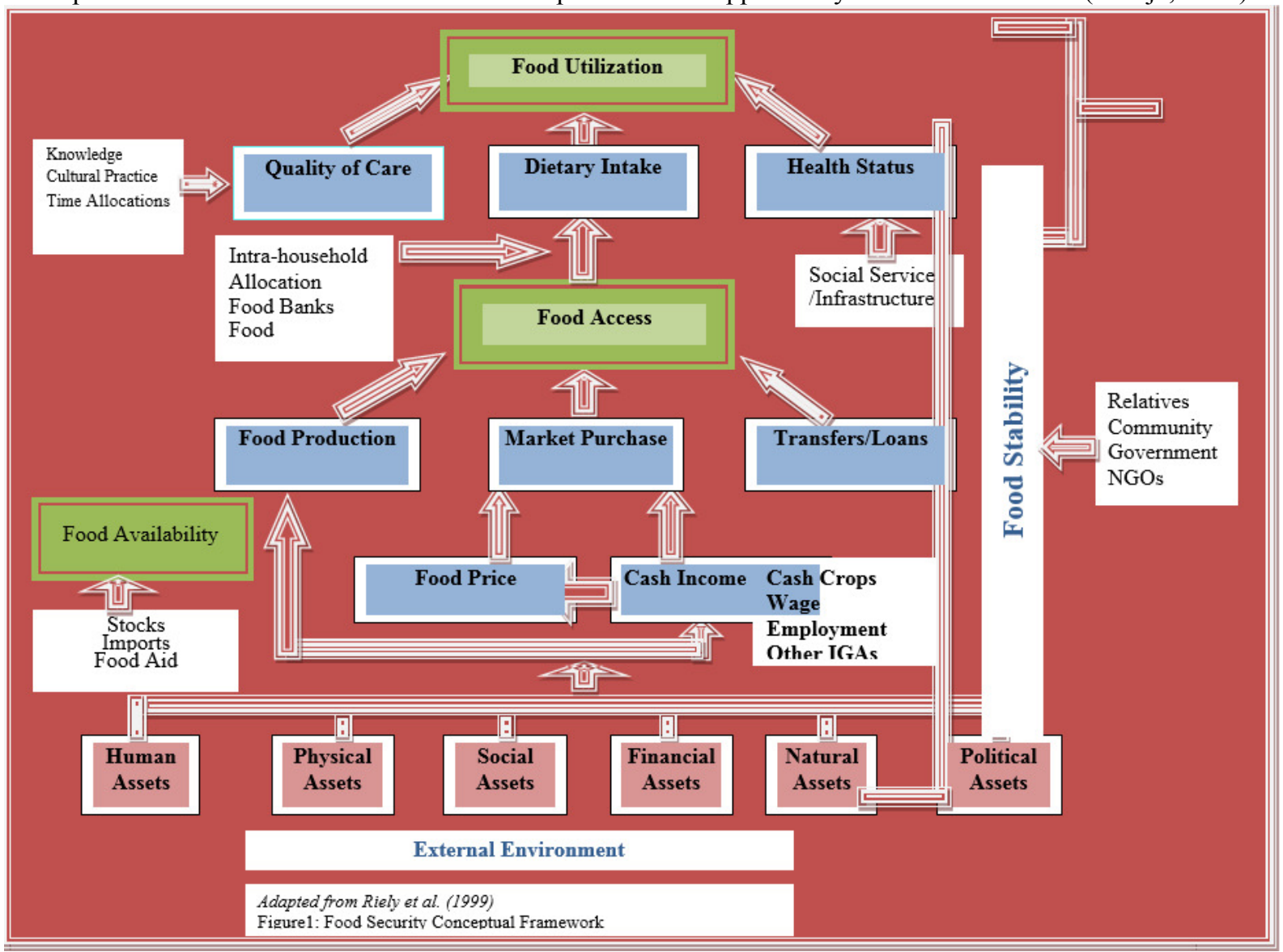

Lay Gayint is one of the food insecure Woredas of South Gondar Zone in Amhara National Regional State, Ethiopia. The Woreda covers an area of $1,548.56 \mathrm{~km}^{2}$ and sub-divided into 29 rural and two urban Kebeles (the lowest administrative unit of Ethiopia). It is bordered in the North by Ebnat and Bugna, in the south by Tach Gayint and Simada, in the west by Estie and Farta Woredas and in the East by Mekiet Woreda of North Wollo Zone. The absolute location of the Woreda is $11^{\circ} 32^{\prime}-12^{\circ} 16^{\prime} \mathrm{N}$ Latitude to $38^{\circ} 12^{\prime}-38^{\circ} 20^{\prime} \mathrm{E}$ Longitude. The administrative center is Nefas Mewcha; it is located on the way from Woreta to Woldia high way which is 226 Kms away from Gondar city and $175 \mathrm{kms}$ away from the regional capital city, Bahir Dar (Lay Gayint Woreda Office of Agriculture, 2014). 


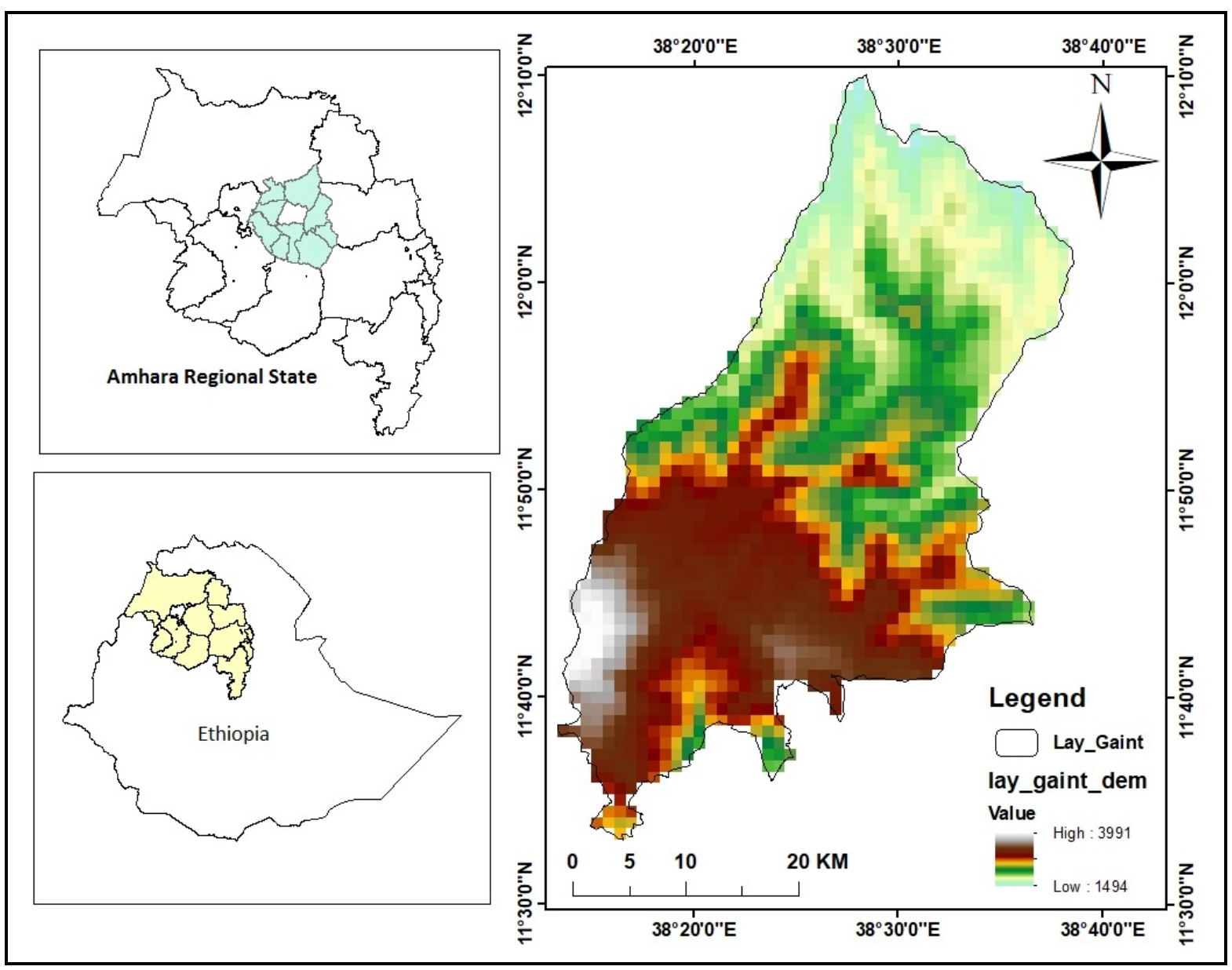

Figure 2: Location Map of Lay Gayint

According to the Woreda Office of Finance and Economic Development (WOoFED) [2014], the elevation of the Woreda ranges from 1,300 to 4,231 meters above sea level. The topography of the Woreda is mostly undulated; hills and valleys extending from Tekeze Gorge (1,500 meter) to Guna Mountain summit $(4,230$ meter above sea level) (masl). Indeed, the Woreda is characterized by $15 \%$ plain, $10 \%$ mountain, $5 \%$ valley and $70 \%$ plateau. Agro-ecologically, the Woreda is classified into three zones, namely: Dega [High Altitude], Woina Dega [Mid Altitude] and Kolla [Low Altitude] covering an area of 34.5\%, $41.4 \%$ and $24.1 \%$ respectively. The mean annual temperature and rainfall of the Woreda is $14^{\circ} \mathrm{C}$ and $600 \mathrm{~mm}$ to $1400 \mathrm{~mm}$ respectively.

The population of the Woreda is 208,249 (Female 102,536). The rural population comprises $88.95 \%$. The Woreda covers about $1,548.56 \mathrm{~km}^{2}$ with a wide variation of elevation. From the total area: $61 \%$ is cultivated land, $20.7 \%$ is grazing land, $7.3 \%$ is covered with forest and bushes, and $11 \%$ is settlement and wasteland. Based on the information obtained from South Gondar Zone Information and Communication Office (2010), most of the rural population is settled in the highlands and plateau areas. The main soil types in the woreda are brown $(55 \%)$, red $(15 \%)$, black $(15 \%)$, grey $(10 \%)$ and other soil type $(5 \%)$ (Lay Gayint Woreda Office of Agriculture/LGWOA, 2010).

The annual mean minimum and maximum temperature and rainfall ranges from $8^{0} \mathrm{c}$ to $29^{\circ} \mathrm{c}$ and $600 \mathrm{~mm}$ to $1,400 \mathrm{~mm}$ respectively. The rainfall is characterized by high variability and uncertainty. The rainfall pattern in the Woreda is uni-modal. Rain usually starts in mid March, but the effective rainy season is from June to mid September (LGWOA, 2010).

Deforestation, overgrazing and absence of appropriate soil and water conservation measures have contributed to the prevalence of drought in the Woreda. The major economic activity being run is mixed agriculture: crop and livestock production (WOoFED, 2014). Currently, 45,154 individuals are under productive safety net program food aid support (LGWOA, 2014).

\section{RESEARCH METHODS}

\subsection{Sampling procedures and techniques}

Lay Gayint Woreda is divided into 29 rural Kebeles. The Woreda has three major agro-ecological zones. 10 of the kebeles fall in Dega, 12 of them fall in Woina Dega and 7 of the Kebeles fall in Kolla agro-ecologies. To 
account for the expected heterogeneity in the samples operating in different agro-ecologies, a stratified two-stage sampling procedure was used. In the first stage, the Woreda was divided into three agro-ecological zones using stratified sampling technique. Two kebeles from Dega, two Kebeles from Woina Dega and one Kebele from Kolla agro-ecological zones were selected proportionally using probability sampling technique. The assumption was that in similar agro- ecological zones, households share similar opportunities and constraints. In the second stage, 379 household heads were drawn from the selected Kebeles, proportional to the size of each Kebele household population, by using systematic sampling technique. A sampling frame is prepared for each of the five Kebeles from 1 to $N$. The sample interval $(k)$ is determined by the formula $(k=N / n)$ where $k$ is the interval, $N$ is the number of total population and $\mathrm{n}$ is the number of sample population. Then a number between 1 and $\mathrm{k}$ is drawn using simple random sampling technique and then every $\mathrm{k}^{\text {th }}$ unit after that first number is selected. The total of every $\mathrm{k}^{\text {th }}$ person in each Kebele are the sample households.

The decision on how many respondents that the study should have to embrace was determined by taking into account the following combination of factors: level of confidence (95\%) and total population in the study area. Yamane (1967) as cited in Mersha (2013) provided a simplified formula; and this was used to calculate sample size.

Where:

$\mathrm{N}$

$$
\mathrm{n}=\frac{}{1+\mathrm{N}(\mathrm{e})^{2}}
$$

$\mathrm{n}=$ Sample size the research uses;

$\mathrm{N}=$ Total number of households in all the Kebeles;

$\mathrm{e}=$ Maximum variability or margin of error $5 \%(0.05)$;

$1=$ Designates the probability of the event occurring.

The sampling procedure is figuratively presented as follows:

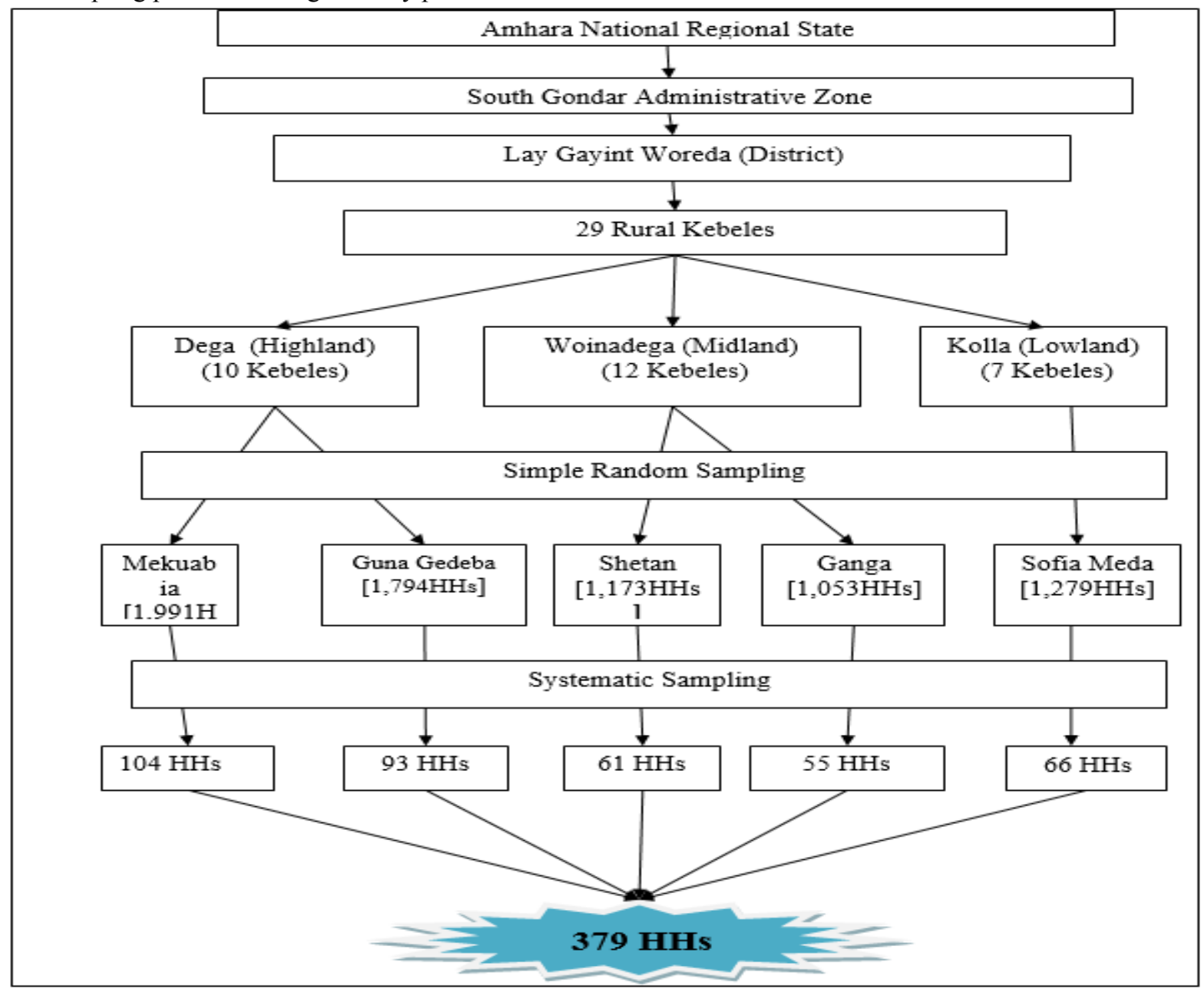

Figure 2: Sketch of sampling procedures and techniques

HHs - Households 


\subsection{Source of Data and Method of Data Collection}

For this study, both primary and secondary data were collected. Primary data were collected from 379 sampled respondents through questionnaire survey which has brought this study to fruition. To collect a range of quantitative data on food security indicators, a household survey was used. The data sets are important for calculating food security scales and computing percentage values for comparison between food secure and food insecure households.

A standard tool known as Core Food Security Module (CFSM) which has close ended questionnaires related to food insecurity status were oriented to enumerators, tested practically and used to collect data from the sampled respondents. To maintain data validity and reliability, experts in natural resource management, food security and disaster risk management reviewed the survey questions. Besides, the survey questions were pretested by distributing questionnaires to non-sampled household heads who were not included in the actual survey. Amendments were made through modifying confusing questions based on the comments from experts and observations of households' responses. The corresponding author has given training to data collectors with respect to the survey techniques and confidentiality protocol.

Data collectors who were given the training administered the household survey with close supervision of the authors in the period from January to March 2015. In the absence of respondent households, the spouses were contacted. When challenges faced to meet the selected households due to absenteeism, households next to them in the list were taken to replace them. Most of the farmers were contacted on their homesteads and few of them around churches and community gathering places. As the data collectors have been living in the community for many years, they better know the area and easily approach and handle respondents.

Secondary data were collected from published and unpublished sources to substantiate findings of the primary data.

\subsection{Methods of Data Analysis}

This study employed a measurement tool, Core Food Security Module (CFSM) to measure the extent of household food insecurity status over selected 12 months. Indicators are constructed from a set of food security related observations. These are classified according to a set of criteria, aggregated, and placed in some relevant perspective. In most analyses of food security conditions, multiple indicators are used to reflect the various dimensions of the problem (Reily et al., 1999).

The Food Security Questionnaire is the most comprehensive and widely used food security measure. The strength of the module is that it contains multiple indicator questions which capture and differentiate among the different levels of severity that result from an inadequate food supply. The other strength of the Core Module is that the findings are readily interpretable. The Core Food Security Module (CFSM) is designed to use it both in national surveys and for local groups who want to determine the extent and severity of food insecurity and hunger. Household's level of food insecurity or hunger should be determined by obtaining information on a variety of specific conditions, experiences, and behaviors that serve as indicators of the varying degrees of severity of the condition. The core module (Q2-Q16, plus three skip-pattern follow-up questions) provides the smallest set of indicators that will allow implementation of the full range of the food security scale.

The scale contains 10 items for households without children and 18 items for households with children. Hence, a complete response requires either 18 or 10 valid answers. The next step is to do counting of the number of affirmative responses for each of the households. The food security scale values and status-level classifications are both determined by referencing to a table containing standard values estimated for food security data. Both the scale value and the status-level classification of each survey household depend on the number of affirmative responses the respondent has given and whether the household has children. To decide the scale value and classification for a household, select the column corresponding to the household type (with or without children) and select the row corresponding to the total number of affirmative answers by the household (Wunderlich and Norwood, 2006).

According to Opsomer et al. (2002), the model which was used to develop food security scale, can be written in terms of the log of the odds ratio expressed as the difference between the severity of the household's food insecurity and the level of food insecurity (difficulty) the household experienced. It is expressed as:

$$
\operatorname{Pr}\left(I_{i j}=1 / \theta_{i}, \alpha_{j}\right)=\frac{\operatorname{Exp}^{\left(\theta_{i}\right.} \frac{\left.\alpha_{j}\right)}{\left.1+\operatorname{Exp}^{\left(\theta_{i}-\right.} \alpha_{j}\right)}}{1+e^{\left(\theta_{i}-\alpha_{j}\right)}}
$$

Where,

$I_{i j}$ - is random variable that gives the dichotomous answer of person $i$ to item $j$

$\theta_{i}-$ the $i^{\text {th }}$ individual's ability parameter for $i=1 \ldots n$

$\alpha_{j}$ - the $j^{\text {th }}$ item's difficulty parameter for $j=1 \ldots m$ 
e - the base of natural logarithms

Pr- probability

Table 1. The Core Food Security Module Questionnaire

\begin{tabular}{|c|c|c|c|}
\hline \multicolumn{2}{|r|}{ Core Food Security Module Questions and Answer Categories } & How often in the last 12 months & Mark \\
\hline \multicolumn{4}{|c|}{ Stage 1 ( $1^{\text {st }}$ Level Screen $)$} \\
\hline \multirow[b]{4}{*}{2} & \multirow{4}{*}{$\begin{array}{l}\text { (I/We) worried whether (my/our) food would run out before } \\
\text { (I/we) got money to buy more. }\end{array}$} & Often true & \\
\hline & & Sometimes true & \\
\hline & & Never true & \\
\hline & & DK or $\mathrm{R}$ & \\
\hline \multirow[b]{4}{*}{3} & \multirow{4}{*}{$\begin{array}{l}\text { The food that (I/we) bought just didn't last, and (I/we) didn't } \\
\text { have money to get more. }\end{array}$} & Often true & \\
\hline & & Sometimes true & \\
\hline & & Never true & \\
\hline & & DK or $\mathrm{R}$ & \\
\hline \multirow[b]{4}{*}{4} & \multirow[b]{4}{*}{ (I/we) couldn't afford to eat balanced meals. } & Often true & \\
\hline & & Sometimes true & \\
\hline & & Never true & \\
\hline & & DK or $\mathrm{R}$ & \\
\hline \multirow[b]{4}{*}{5} & \multirow{4}{*}{$\begin{array}{l}\text { (I/we) relied on only a few kinds of low-cost food to feed } \\
\text { (my/our child/the children) because (I was/we were) running } \\
\text { out of money to buy food. }\end{array}$} & Often true & \\
\hline & & Sometimes true & \\
\hline & & Never true & \\
\hline & & DK or $\mathrm{R}$ & \\
\hline \multirow[b]{4}{*}{6} & \multirow{4}{*}{$\begin{array}{l}\text { (I/we) couldn't feed (my/our child/the children) a balanced } \\
\text { meal, because (I/we) couldn't afford that. }\end{array}$} & Often true & \\
\hline & & Sometimes true & \\
\hline & & Never true & \\
\hline & & DK or $\mathrm{R}$ & \\
\hline
\end{tabular}

\begin{tabular}{|c|c|c|c|}
\hline \multicolumn{4}{|c|}{ Stage 2 ( $2^{\text {nd }}$ Level Screen) } \\
\hline \multirow[b]{4}{*}{7} & \multirow{4}{*}{$\begin{array}{l}\text { (My/Our child was/The children were) not eating enough } \\
\text { because (I/we) just couldn't afford enough food. }\end{array}$} & Often true & \\
\hline & & Sometimes true & \\
\hline & & Never true & \\
\hline & & DK or $\mathrm{R}$ & \\
\hline \multirow[b]{3}{*}{8} & \multirow{3}{*}{$\begin{array}{l}\text { Did (you/you or other adults in your household) ever cut the } \\
\text { size of your meals or skip meals because there wasn't } \\
\text { enough money for food? }\end{array}$} & Yes & \\
\hline & & No (Skip 8a) & \\
\hline & & DK or R (Skip 8a) & \\
\hline \multirow[b]{4}{*}{$8 \mathrm{a}$} & \multirow{4}{*}{ If yes for 8, How often did this happen? } & Almost every month & \\
\hline & & Some but not every month & \\
\hline & & Only 1-2 months & \\
\hline & & DK or $\mathrm{R}$ & \\
\hline \multirow[b]{3}{*}{9} & \multirow{3}{*}{$\begin{array}{l}\text { Did you ever eat less than you felt you should because there } \\
\text { wasn't enough money to buy food? }\end{array}$} & Yes & \\
\hline & & No & \\
\hline & & DK or $\mathrm{R}$ & \\
\hline \multirow[b]{3}{*}{10} & \multirow{3}{*}{$\begin{array}{l}\text { Were you ever hungry but didn't eat because you couldn't } \\
\text { afford enough food? }\end{array}$} & Yes & \\
\hline & & No & \\
\hline & & DK or $\mathrm{R}$ & \\
\hline \multirow[b]{3}{*}{11} & \multirow{3}{*}{$\begin{array}{l}\text { Did you lose weight because you didn't have enough money } \\
\text { for food? }\end{array}$} & Yes & \\
\hline & & No & \\
\hline & & DK or $\mathrm{R}$ & \\
\hline \multicolumn{4}{|c|}{ Stage 3 (3rd Level Screen) } \\
\hline \multirow[b]{3}{*}{12} & \multirow{3}{*}{$\begin{array}{l}\text { Did (you/ or other adults in your household) ever not eat for } \\
\text { a whole day because there wasn't enough money for food? }\end{array}$} & Yes & \\
\hline & & No (Skip 12a) & \\
\hline & & DK or R (Skip 12a) & \\
\hline \multirow[b]{4}{*}{$12 \mathrm{a}$} & \multirow[b]{4}{*}{ If yes to 12, how often did this happen? } & Almost every month & \\
\hline & & Some but not every month & \\
\hline & & Only 1-2 months & \\
\hline & & DK or $\mathrm{R}$ & \\
\hline \multirow[b]{3}{*}{13} & \multirow{3}{*}{$\begin{array}{l}\text { Did you ever cut the size of (your child's/any of the } \\
\text { children's) meals because there wasn't enough money for } \\
\text { food? }\end{array}$} & Yes & \\
\hline & & No & \\
\hline & & DK or $\mathrm{R}$ & \\
\hline
\end{tabular}




\begin{tabular}{|c|c|c|c|}
\hline \multicolumn{2}{|r|}{ Core Food Security Module Questions and Answer Categories } & How often in the last 12 months & Mark \\
\hline \multirow[b]{3}{*}{14} & \multirow{3}{*}{$\begin{array}{l}\text { Did (your child/any of the children) ever skip a meal } \\
\text { because there wasn't enough money for food? }\end{array}$} & Yes & \\
\hline & & No (Skip 14a) & \\
\hline & & DK or R (Skip 14a) & \\
\hline \multirow[b]{4}{*}{$14 \mathrm{a}$} & \multirow[b]{4}{*}{ If yes for 14, How often did this happen? } & Almost every month & \\
\hline & & Some but not every month & \\
\hline & & Only 1-2 months & \\
\hline & & DK or $\mathrm{R}$ & \\
\hline \multirow[b]{3}{*}{15} & \multirow{3}{*}{$\begin{array}{l}\text { (Was your child/Were the children) ever hungry but you just } \\
\text { couldn't afford more food? }\end{array}$} & Yes & \\
\hline & & No & \\
\hline & & DK or $\mathrm{R}$ & \\
\hline \multirow[b]{3}{*}{16} & \multirow{3}{*}{$\begin{array}{l}\text { Did (your child/any of the children) ever not eat for a whole } \\
\text { day because there wasn't enough money for food? }\end{array}$} & Yes & \\
\hline & & No & \\
\hline & & DK or $\mathrm{R}$ & \\
\hline
\end{tabular}

Note: DK implies "I do not Know" While R implies "Refusal to respond"

Table 1 presents the Core Food Security Module Questionnaire which contains 10 and 18 items for households without and with children respectively. The questions highlighted with dark are questions for households with children, whereas the rest of the questions are for both households with and without children. In the response column, the ones highlighted with dark are categorized as affirmative responses while the rest response options are negative responses. These essential items were used to decide the rural households' levels of food security based on the standards estimated for the purpose (see Table 2).

Table 2: Core food security status level with food security scale value

\begin{tabular}{|c|c|c|c|c|c|}
\hline \multicolumn{2}{|c|}{ Number of affirmative responses } & \multirow{2}{*}{$\begin{array}{l}\text { Food Security } \\
\text { Scale values }\end{array}$} & \multicolumn{3}{|c|}{ Food security status } \\
\hline $\begin{array}{l}\text { (Out of 18) households } \\
\text { with children }\end{array}$ & $\begin{array}{l}\text { (Out of 10) households } \\
\text { without children }\end{array}$ & & Code & \multicolumn{2}{|c|}{ Category } \\
\hline 0 & 0 & 0.0 & \multirow{5}{*}{0} & \multirow{5}{*}{\multicolumn{2}{|c|}{ Food Secure }} \\
\hline \multirow[t]{2}{*}{1} & & 1.0 & & & \\
\hline & 1 & 1.2 & & & \\
\hline \multirow[t]{2}{*}{2} & & 1.8 & & & \\
\hline & 2 & 2.2 & & & \\
\hline 3 & & 2.4 & \multirow{24}{*}{1} & \multirow{24}{*}{$\begin{array}{l}\text { Food } \\
\text { insecure }\end{array}$} & \multirow{8}{*}{$\begin{array}{l}\text { Food insecure } \\
\text { without } \\
\text { hunger }\end{array}$} \\
\hline \multirow[t]{2}{*}{4} & & 3.0 & & & \\
\hline & 3 & 3.0 & & & \\
\hline \multirow[t]{2}{*}{5} & & 3.4 & & & \\
\hline & 4 & 3.7 & & & \\
\hline 6 & & 3.9 & & & \\
\hline \multirow[t]{2}{*}{7} & & 4.3 & & & \\
\hline & 5 & 4.4 & & & \\
\hline 8 & & 4.7 & & & \multirow{8}{*}{$\begin{array}{l}\text { Food insecure } \\
\text { with } \\
\text { moderate } \\
\text { hunger }\end{array}$} \\
\hline & 6 & 5.0 & & & \\
\hline 9 & & 5.1 & & & \\
\hline 10 & & 5.5 & & & \\
\hline & 7 & 5.7 & & & \\
\hline 11 & & 5.9 & & & \\
\hline \multirow[t]{2}{*}{12} & & 6.3 & & & \\
\hline & 8 & 6.4 & & & \\
\hline 13 & & 6.6 & & & \multirow{8}{*}{$\begin{array}{l}\text { Food insecure } \\
\text { with severe } \\
\text { hunger }\end{array}$} \\
\hline \multirow[t]{2}{*}{14} & & 7.0 & & & \\
\hline & 9 & 7.2 & & & \\
\hline \multirow[t]{2}{*}{15} & & 7.4 & & & \\
\hline & 10 & 7.9 & & & \\
\hline 16 & & 8.0 & & & \\
\hline 17 & & 8.7 & & & \\
\hline 18 & & 9.3 & & & \\
\hline
\end{tabular}

Table 2 presents the core food security status of rural households with food security scale value. We can clearly see from the table above that the households were classified as food secure or food insecure following the standard values estimated for food security data. The food insecure category was further classified into food 
insecure with no, moderate and severe hunger (see Table 2). The statistical procedure for determining a household's scale value is basically depend on the number of increasingly severe indications of food insecurity that the household has experienced, as indicated by affirmative responses to the increasingly severe sequence of survey questions. A household with a scale value of 7 , for example, has responded affirmatively to more, and typically to more severe, indicators of food insecurity than a household with a scale value of 4 . A household that has not experienced any of the questions covered by the core module questions will be assigned a scale value of 0 , while a household that has experienced all of them will have a scale value close to 10 .

\section{RESULTS}

Timely reliable information is essential to inform policy-makers about the status of food security, to get them ready, and to suggest possible coping and adaptation measures. The main purpose of this study was to determine the food security status of rural households in Lay Gayint Woreda of South Gondar Administrative Zone, Amhara Regional State, Ethiopia. To achieve the objective of this study, data were collected from 379 randomly selected rural households. Once the data collection was completed, data processing (editing, coding, classification and Tabulation) was done. Statistical Package for Social Sciences (SPSS) Version 16 was used. The results are organized into two sections. The first section highlights the socio-demographic characteristics of sample households and the second section presents the rural households' food security status in the study area.

\subsection{Socio-demographic profiles of the respondents}

A total of 379 rural household heads were asked and completed the survey questionnaire. Among these 379 participants, 323(85.2\%) were males while the majority age group 299 (78.9\%) were aged between 31 and 64 with the mean age of 46.2 years. $228(60.2 \%)$ and $151(39.8 \%)$ of the respondents were having a family size of 1-5 and 6-9 respectively; the mean family size of the sampled households was founded to be 5.17. Indeed, 200 $(52.8 \%), 173(45.6 \%)$ and $6(1.6 \%)$ of the respondents had a dependency ratio (the ratio of non-productive age group to the productive age group) of $0-1,1.01-2$ and $2.01-3$ respectively with the mean dependency ratio of 0.90 . Slightly over half $202(53.3 \%)$ of the respondents were illiterate (see Table 3 ).

Table 3: Socio-Demographic Characteristics of the Sampled Households

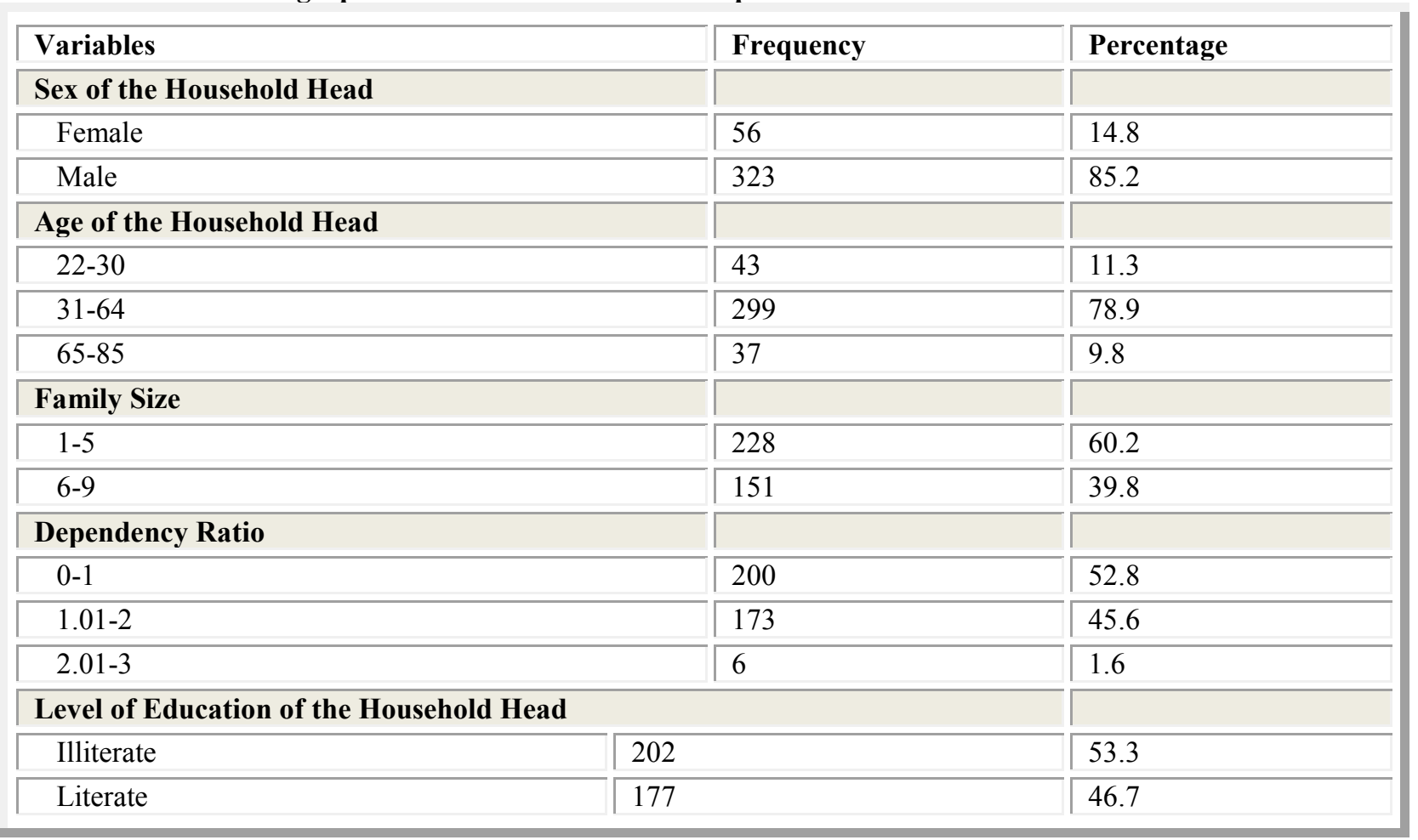

Source: Own Survey Result, March 2015

\subsection{Food security Status of Rural Households}

As it is already discussed in the preceding sections this study employed the Core Food Security Module (CFSM) as a measurement tool to determine the extent of rural households' food insecurity status over selected 12 months based on the indicators developed from a set of food security related observations in Lay Gayint Woreda of Amhara National Regional State, Ethiopia. Therefore, this section presented the results of data collected using 
the household questionnaire survey designed to measure households' food security status (see Tables 4 - 6).

Table 4: Frequency distribution of household affirmative responses $(\mathrm{N}=379)$

\begin{tabular}{|c|c|c|c|}
\hline \multicolumn{2}{|c|}{ Households with children (Out of 18) } & \multicolumn{2}{|c|}{ Households without children (Out of 10) } \\
\hline Number of affirmative response & Frequency & Number of affirmative response & Frequency \\
\hline 0 & 0 & 0 & 2 \\
\hline \multirow[t]{2}{*}{1} & 2 & & \\
\hline & & 1 & 0 \\
\hline \multirow[t]{2}{*}{2} & 43 & & \\
\hline & & 2 & 10 \\
\hline 3 & 0 & & \\
\hline \multirow[t]{2}{*}{4} & 0 & & \\
\hline & & 3 & 0 \\
\hline \multirow[t]{2}{*}{5} & 0 & & \\
\hline & & 4 & 0 \\
\hline 6 & 23 & & \\
\hline \multirow[t]{2}{*}{7} & 44 & & \\
\hline & & 5 & 3 \\
\hline \multirow[t]{2}{*}{8} & 0 & & \\
\hline & & 6 & 2 \\
\hline 9 & 21 & & \\
\hline \multirow[t]{2}{*}{10} & 24 & & \\
\hline & & 7 & 3 \\
\hline 11 & 32 & & \\
\hline \multirow[t]{2}{*}{12} & 32 & & \\
\hline & & 8 & 6 \\
\hline 13 & 30 & & \\
\hline \multirow[t]{2}{*}{14} & 26 & & \\
\hline & & 9 & 4 \\
\hline \multirow[t]{2}{*}{15} & 28 & & \\
\hline & & 10 & 2 \\
\hline 16 & 23 & & \\
\hline 17 & 16 & & \\
\hline 18 & 3 & & \\
\hline Total & 347 & & 32 \\
\hline
\end{tabular}

Source: Own survey result, April, 2014 - March, 2015

The frequencies of affirmative responses of the surveyed households for the items listed in Table 1 are summarized in Table 4 above. 347 households with children of under age 18 and 32 households without children of under age 18 have a valid response to the survey questionnaire .Once the number of positive responses are determined, the food security scale values and status-level classifications ( food secure, food insecure without hunger, food insecure with moderate hunger and food insecure with severe hunger) will then be decided by referencing to the standard values set for food security data (Table 2: Core food security status level with food security scale value). 
Table 5: Frequency distribution of household food security scale value $(\mathrm{N}=379)$

\begin{tabular}{|c|c|c|c|c|}
\hline Scale Value & Frequency & Percent & Cumulative Percent & Remark \\
\hline 0 & 2 & 0.5 & 0.5 & \multirow{4}{*}{ Food Secure } \\
\hline 1 & 2 & 0.5 & 1.1 & \\
\hline 1.8 & 41 & 10.8 & 11.9 & \\
\hline 2.2 & 12 & 3.2 & 15.0 & \\
\hline 3.9 & 23 & 6.1 & 21.1 & \multirow{3}{*}{$\begin{array}{c}\text { Food Insecure without } \\
\text { Hunger }\end{array}$} \\
\hline 4.3 & 44 & 11.6 & 32.7 & \\
\hline 4.4 & 3 & 0.8 & 33.5 & \\
\hline 5 & 2 & 0.5 & 34.0 & \multirow{7}{*}{$\begin{array}{l}\text { Food Insecure with } \\
\text { Moderate Hunger }\end{array}$} \\
\hline 5.1 & 21 & 5.5 & 39.6 & \\
\hline 5.5 & 24 & 6.3 & 45.9 & \\
\hline 5.7 & 4 & 1.1 & 47 & \\
\hline 5.9 & 31 & 8.2 & 55.1 & \\
\hline 6.3 & 30 & 7.9 & 63.1 & \\
\hline 6.4 & 8 & 2.1 & 65.2 & \\
\hline 6.6 & 30 & 7.9 & 73.1 & \multirow{8}{*}{$\begin{array}{l}\text { Food Insecure with } \\
\text { Severe Hunger }\end{array}$} \\
\hline 7 & 26 & 6.9 & 79.9 & \\
\hline 7.2 & 5 & 1.3 & 81.3 & \\
\hline 7.4 & 27 & 7.1 & 88.4 & \\
\hline 7.9 & 2 & 0.5 & 88.9 & \\
\hline 8 & 23 & 6.1 & 95.0 & \\
\hline 8.7 & 16 & 4.2 & 99.2 & \\
\hline 9.3 & 3 & 0.8 & 100 & \\
\hline Total & 379 & 100.0 & 100.0 & \\
\hline
\end{tabular}

Source: Own Survey Result, April, 2014 - March, 2015

Using the reference table (Table 2), the affirmative responses of each surveyed household is converted to food security scale value and after that categorized into food secure and food insecure household without, moderate and severe hunger. Households whose food security scale value less than or equal to 2.2 , the divide line for food secure and food insecure households are 57 while those households with food security scale value greater than 2.2 are 322 showing that majority of households have faced with food security problems.

Table 6: Summary of percentage distribution of households' food security status $(\mathrm{N}=379)$

\begin{tabular}{|l|r|r|r|r|}
\hline \multirow{2}{*}{ Categories } & \multicolumn{2}{l|}{ Households } & \multicolumn{2}{l|}{ Food Security Scale Value } \\
\cline { 2 - 5 } & Count & Percentage & Mean & \multicolumn{1}{c|}{ S.D } \\
\hline Food Secure & 57 & 15 & 1.779 & 0.408 \\
\hline Food Insecure without Hunger & 70 & 18.5 & 4.173 & 0.193 \\
\hline Food Insecure with Moderate Hunger & 120 & 31.7 & 5.792 & 0.451 \\
\hline Food Insecure with Severe Hunger & 132 & 34.8 & 7.446 & 0.730 \\
\hline Total & 379 & 100 & 5.465 & 2.010 \\
\hline
\end{tabular}

Source: Household Survey, April, 2014 - March, 2015

The Core Food Security Module result showed that 57 households (15\%) are food secure, 70 households $(18.5 \%)$ are food insecure without hunger, 120 households $(31.7 \%)$ are food insecure with moderate hunger and 132 households $(34.8 \%)$ are food insecure with severe hunger (Table 6). The mean food security scale value of the surveyed households is 5.465 while the standard deviation is 2.010 implying that the food security situation is serious and there is more variation in the food security scale value of households.

\section{DISCUSSION}

As it is already discussed in the background section of the paper, food is a fundamental right that influences human ability to exist, grow well and acquire information and skill. Adequate food is necessary for optimal physical, cognitive and emotional development and function of human beings at all stages of the lifespan. However, given the many unwanted impacts connected with poverty and hunger, food insecurity is a priority threat to the well-being of human beings. Food insecurity is a severe problem more in the poor agrarian nations like Ethiopia. This study was conducted to measure rural households' food security status in Lay Gayint Woreda, South Gondar Zone of Amhara National Regional State, Ethiopia.

Food insecurity at household level is best measured by direct surveys of expenditure, income, consumption, and comparing it with the minimum subsistence requirement. However, in this study the household food security module measurements were taken to compute proxy indicators of food insecurity. In the light of this, the Core 
Food Security Module result showed that $85 \%$ the surveyed households were food insecure: $18.5 \%$ food insecure without hunger, $31.7 \%$ food insecure with moderate hunger and $34.8 \%$ food insecure with severe hunger while only $15 \%$ of the surveyed households were food secure (Refer to Table 6). Like elsewhere, in Ethiopia agriculture is the most vulnerable sector including land and water. The studied Woreda is highly vulnerability to climate change-induced risks as it has suffered from climate variability and weather extremes. Rain shortage and variability have caused crop failures. Recurrent droughts, hailstorms and severe erosions on the fragile ecosystems have increased the probability of risks on poor people's livelihood resources.

The result of this study supported Ethiopian government's concern about the Woreda. The government classified the Woreda as food insecure on the basis of the criteria set and used for determining food secure and food insecure places to implement the government Productive Safety Net Program (PSNP) in different Regional States of Ethiopia. Due to the fragile nature of the Woreda's landscape, natural resources management efforts and agricultural extension packages planned for production and productivity gain for which millions of dollars have been spent over the last three decades are badly challenged. The recently designed participatory integrated watershed development plans to improve environmental sustainability, improve natural resource base and food security and then to reduce poverty have continued to be difficult in the Woreda. Still, environmental problems exacerbated the problem. Land management structures short lived, underprivileged people's livelihood bases disrupted, traditional coping mechanisms failed, conflict over scarce resources increased, food insecurity continued as a problem, and dependency on external support is still common. This implies that climate change and land degradation are intimately interlinked in creating adverse effects on natural and human systems. Tesfaye (2003) argued that the legacy of the previous efforts did not leave northern Ethiopia with the outcomes promised three decades ago, regarding sustainable land use, food security, and natural resource management.

In the light of this study, African Climate Change Resilience Alliance/ACCRA [2011\} noted that food insecurity is more pronounced when there is interaction with other non-climatic stresses. Farmers, experts, extension officers, and animal health workers iterated that drought, flood, pests, and diseases have increased in recent 10-20 years as compared to the previous decades. They also revealed the emergence of new pests, diseases, and invasive weed species.

Joint research done by Yohannes and Peter as cited in Abi (2001), also have come up with similar findings in low potential areas of Amhara Region. According to the results of their study, only $15 \%$ of the farming households were capable of fulfilling their basic needs from agricultural activities. With the addition of off-farm activities, approximately $30 \%$ of the households were able to cover necessary needs from farming activities while about $70 \%$ of them were unable to generate adequate income from any means to secure household food needs.

The majority of the surveyed households associated food insecurity with the impact of drought, soil erosion and increased frequency of crop as well as animal pests and disease. Farmlands' location in a fragile landscape increase the intensity of soil erosion, and results in poor soil fertility thereby contribute much to households' reduced agricultural productivity. Furthermore, other non-climatic factors like inadequate extension services, poor access to modern inputs or ineffectiveness of modern fertilizers, inadequate access to financial service were mentioned.

The magnitude and rate of current climate variability, climate change, and other extreme events joined with environmental, social, and political factors are negatively influencing many traditional coping strategies ineffective and/or unsustainable which in turn forced households to find new strategies. This implies that rural households in the study area are more vulnerable to chronic and transitory food insecurity indicating that resources which have been spent on food insecure households to improve their food security status did not bring the desired result. This could be due to lack of sufficient study to identify, design and implement interventions that take into account the local context. Therefore, more attention is required to find improved local specific pathway that leads to ensuring food security of vulnerable rural households with a shorter period of time.

\section{CONCLUSIONS}

Understanding food security status would help policy makers to design and implement more effective policies and programs that benefit the poor and thereby help to pave ways to ensure food security. The purpose of this study was to carry out empirical estimation of rural households' food security status in Lay Gayint Woreda, South Gondar zone, Amhara National Regional State, Ethiopia.

The output of this study revealed that only $15 \%$ of the sampled rural households were found to be food secure and in turn significant portion of the community is dependent on foreign food donations like in the name of Productive Safety Net Programs (PSNP), Joint Emergency Operation Programs (JEOP) and others. The food insecurity situation looks much severe despite the government effort which has been exerted to ensure food security. Communities and Woreda officials realized negative outcomes of drought and extreme weather events on the natural resources base including small size and poor quality of farmlands. This has called for finding 
potential (new) pathways that will lead to lifting up of rural households from food insecurity. This study, therefore, suggests multitude and multi-level policy and research interventions for enhancing community-based participatory integrated watershed management approach supported with best farmers' indigenous knowledge and practices. In order to reduce population pressure on the scarce resources family planning, education and awareness raising programs, diversification of income by engaging rural households into off-farm/non-farm income generating activities and making the technologies applicable to the end users and proper management of livestock and related service based on the farmers' resource capacity are very crucial.

Local leaders should enforce environmental management efforts through integrating terrace construction and tree plantations that enable to reduce environmental risks of droughts, soil erosion and floods.

$\begin{array}{ll}\text { Abbreviations } & \\ \text { ACCRA } & \text { African Climate Change Resilience Alliance } \\ \text { CFSM } & \text { Core Food Security Module } \\ \text { FAO } & \text { Food and Agriculture Organization } \\ \text { HH } & \text { Household } \\ \text { JEOP } & \text { Joint Emergency Operation Programs } \\ \text { masl } & \text { meters above sea level } \\ \text { mm } & \text { millimeter } \\ \text { NGO } & \text { Non Governmental Organization } \\ \text { ORDA } & \text { Organization for Rehabilitation and Development in Amhara } \\ \text { PSNP } & \text { Productive Safety Net Program } \\ \text { SSA } & \text { Sub Saharan Africa } \\ \text { SPSS } & \text { Statistical Package for Social Sciences } \\ \text { WOoFED } & \text { Woreda Office of Finance and Economic Development }\end{array}$

Ethics approval and consent to participate

Not applicable by the university. Only researches on heath are obliged to have ethical clearance.

\section{Consent for publication}

Not applicable in this section.

\section{Availability of data and materials}

The datasets generated and/or analyzed during the current study are not publicly available due absence of publicly archived datasets in the newly established university system but are available from the corresponding author on reasonable request.

\section{Competing Interests}

The authors declare that there is no conflict of interest regarding the publication of this paper.

\section{Funding}

The funding bodies, Organization for Rehabilitation and Development in Amhara (ORDA) and University of Gondar, had no any role in the design of the study and collection, analysis, and interpretation of data and in writing the manuscript.

\section{Authors' contributions}

GZ has made substantial contributions in designing the research, acquisition of the necessary data, interpretation of results and leading the research activities. MT has guided, reviewed the proposal, the data collection tools, supervised and he was the major contributor in writing and editing the manuscript. Both authors have given also the final approval of the version to be published.

\section{ACKNOWLEDGEMENTS}

We are very much grateful for the partial financial support of Organization for Rehabilitation and Development in Amhara (ORDA) and University of Gondar. We thank to the genuine support and encouragement of all the staff of the Lay Gayint project office. All the respondents and other collaborated individuals also deserve special thanks for their valuable time and work during data collection.

\section{REFERENCES}

Abi, M. (2001). Chronic Food Insecurity in Ethiopia: looking Through a Livelihood lens. Proceedings of the Symposium of the Forum for Social Studies, 10-11 March 2000, Addis Ababa: Forum for Social Studies. 
ACCRA/African Climate Change Resilience Alliance. (2011). Understanding the Influence of Development Interventions on Adaptive Capacity at Local Level in Ethiopia, Africa Climate Change Resilience Alliance (ACCRA) Ethiopia Synthesis Report. Addis Ababa: Africa Climate Change Resilience Alliance (ACCRA).

Bickel, Gary, Mark Nord, Cristofer Price, William Hamilton and John Cook: Guide to Measuring

Household Food Security, Revised 2000. U.S. Department of Agriculture, Food and Nutrition Service, Alexandria VA. March, 2000. Retrieved from www.ers.usda.gov/briefing/foodsecurity

Carlson, S.J., Andrews, M.S., Biekel, G.W. (1999). Measuring Food Insecurity and Hunger in the United States: Development of a National Benchmark Measure and Prevalence Estimate.

Cook, J.T., and Frank D.A. (2008). Food Security, Poverty and Human Development in the United States. Annals of the New York Academy of Sciences, 1136:193-209.

Dereje, K. (2005). Analysis of Gender Based Household Food Security in Kurfa Chale Woreda of Oromia, Ethiopia (unpublished master's thesis, Alamaya University).

Food and Agricultural Organization (FAO). (2009). Coping with a Changing Climate: Considerations for Adaptation and Mitigation in Agriculture. Rome: Food and Agricultural Organization/FAO.

FAO, IFAD and WFP (2013). The State of Food Insecurity in the World .The multiple dimensions of food security. Rome, FAO.

Genene, T. (2006). Farmers' Perceptions of Land Degradation and Determinants of Household Food Security Status at Middle Catchments of Bilate Watershed (Master's Thesis, Addis Ababa University).

Gezahegn, K. (1995). Food Security, Nutrition and Poverty Alleviation Ethiopia: Problems and Prospects. Proceedings: Inaugural and First Annual Conference of the Agricultural Economics Society of Ethiopia, Addis Ababa (Ethiopia), 8-9 June 1995.

Girma, Z. \& Ebrahim, E. (2015). Land Use and Land Cover Dynamics: Driving Forces and Impacts in Lay Gayint Woreda of Amhara National Regional State, Ethiopia. Ethiopian Renaissance Journal of Social and Sciences and the Humanities (ERJSSH), 57-72.

Guled, A. (2006). Food Insecurity and Copping Strategies of Agro-pastoral Household in Awbare Woreda, Somali Region, Ethiopia. (unpublished master's thesis, Addis Ababa University).

Hahn, M. B., Riedere, A. M., \& Foster, S. O. (2009). The Livelihood Vulnerability Index: A Pragmatic Approach to Assessing Risks from ClimateVariability and Change - A Case Study in Mozambique. Global Environmental Change, Article in press, Elsevier Ltd, 1-15.

Hoddinott, J. (1999). Operationalizing Household Food Security in Development Projects: An Introduction. U.S.A: Washington, D.C. 20006.

Keatinge, J.D.H., Yang, R.Y., Hughes, J.d'A., Easdown, W.J., and Holmer, R. (2011). The Importance of Vegetables in Ensuring both Food and Nutritional Security in Attainment of the Millennium Development Goals. Food Security: 3(4).

Keino, S., Plasqui, G., van den Borne, Bart. (2014). Household Food Insecurity Access: A Predictor of Overweight and Underweight among Kenyan Women. Agric. Food Secur, 3(2):1-8.

Khush, GS, Lee, S., Cho, JI and Jeon, JS. (2012). Biofortification of Crops for Reducing Malnutrition. Plant Biotechnology Reports, 6:195-202.

Lay Gayint Woreda Office of Agriculture /LGWOA (2010). Annual Report, 2010, Nefas Mewucha (Unpublished)

Lay Gayint Woreda Office of Agriculture. (2014). Annual Report, 2014 (Unpublished office document). Nefas Mewcha.

Lay Gayint Woreda Office of Finance and Economic Development. (2014). Basic Socio-Economic data, 2014 (Unpublished document). Nefas Mewcha.

Mazumdar, S. (2012). Assessing Vulnerability to Chronic Under nutrition among Under-Five Children in Egypt: Contextual Determinants of an Individual Consequence. International Journal of Population Research, 12p.

Meade, Birgit, and Stacey R., (2013). International Food Security Assessment: 2013-2023 (U.S. Department of Agriculture, Economic Research Service, GFA-24).Retrieved from http://www.ers. usda.gov/topics/ international-markets-trade/global-food-security.aspx

Mersha, A. (2013). Farmers' Vulnerability to Drought and their Coping Strategies: In the Case of Lay Gayint Woreda, Amhara Regional State (Unpublished MA Thesis, University of Gondar).

Morduch, J. (1995). Income Smoothing and Consumption Smoothing. Journals of Economic Perspectives, 9:103-114

Government of Ethiopia. (2002). National Food Security Strategy, Addis Ababa.

Opsomer, J.D., Jensen, H.H. \& Pan, S. (2002). An evaluation of the USDA food security measure with generalized linear mixed models. Retrieved fromhttp://lib.dr.iastate.edu/card workingpapers/320/

Reilly, F. Mock, N., Cogill, B., Bailey, L., \& Kenefick, E. (1999). Food Security Indicators and Framework for Use in the Monitoring and Evaluation of Food Aid Programs. Food and Nutrition Technical Assistance Project (FANTA). Retrieved from http://pdf.usaid.gov/pdf_docs/ Pnacgn 170.pdf 
Schipper, E. L. (2004). Exploring Adaptation to Climate Chnage: A Development Perspective. East Angelia: East Angelia University Press.

Seligman, H. Laraia, B. Kushel, M. (2010). Food Insecurity Associated with Chronic Disease among Lowincome NHANES Participants. J Nutr, 140 (2):304-10.

Tefera, M. (2009). Determinants of Household Food Security in Farta District, South Gondar Zone (MAThesis, Addis Ababa University).

Tesfaye, B. (2003). Understanding farmers: Explaining Soil and Water Conservation in Konso, Wolaita and Wello, Ethiopia. Wageningen: Ph.D Thesis, Wageningen University.

World Bank. (2008). The Economics of Adaptation to Climate Change. New York: International Bank for reconstruction and Development.

Wunderlich, G. S. \& Norwood, J. L. (2006). Food Security and Hunger in the United States: An Assessment of the Measure. Washington, D.C. Retrieved from http://www.nap.edu/catalog/11578.

Yilma, M. (2005). Measuring Rural Household Food Security Status and Its Determinants in the Benishangul Gumuz Region, Ethiopia: The Case of Assosa Woreda (MA Thesis, Addis Ababa University). 